\title{
Degradabilidade Ruminal e Digestibilidade Intestinal de Alimentos por Intermédio da Técnica In Situ Associada à do Saco de Náilon Móvel
}

\section{Marcus Vinicius Morais de Oliveira1, Fernando Miranda Vargas Junior², Luis Maria Bonecarrère Sanchez ${ }^{3}$, Wagner Paris ${ }^{4}$, Adriana Frizzo ${ }^{4}$, lone Pereira Haygert ${ }^{4}$, Daniel Montagner ${ }^{4}$, Alexandre Weber $^{4}$, Liliane Cerdótes $^{4}$}

RESUMO - Objetivou-se no presente trabalho verificar a degradação ruminal e a digestibilidade intestinal e total da matéria seca (MS) e da proteína bruta (PB) do farelo de soja, do grão de milho, do melaço em pó, da farinha de peixe, da farinha de penas e do feno de alfafa, por intermédio da técnica de degradabilidade ruminal in situ associada à técnica do saco de náilon móvel. As amostras dos alimentos foram moídas e colocadas em duplicata em sacos de náilon de 10x5 cm (48 micras) nas quantidades de 15 e $5 \mathrm{mg}$ de $\mathrm{MS} / \mathrm{cm}^{2}$ para os alimentos concentrados e feno de alfafa, respectivamente. Os sacos de náilon permaneceram incubados no rúmen de bois holandeses por 0; 2; 6; 8; 24 e 48 h; e $0 ; 8 ; 12 ; 24 ; 48 ; 72$ e 96 horas, respectivamente, sendo depois retirados e sua duplicata inserida no duodeno através de uma cânula. Posteriormente, os sacos foram coletados junto com as fezes. Os valores de degradabilidade efetiva da PB para uma velocidade de passagem de 5\%/hora, para o melaço em pó, grão de milho, farelo de soja, farinha de peixe, farinha de penas e feno de alfafa, foram de 100,00; 62,50; 57,$90 ; 39,30 ; 34,20$ e 60,90\%, respectivamente; a digestibilidade intestinal de 100,00; 96,05; 99,79; 98,19; 96,07 e 94,64\%, respectivamente; e a digestibilidade total de 100,00; 97,86; 99,87; 98,88; 97,35 e 98,09\%, respectivamente. Verificou-se que as proteínas do melaço foram totalmente solúveis no rúmen, sendo as do milho, feno e farelo de soja bastante degradadas, além de possuírem um aproveitamento quase total no intestino. As proteínas das farinhas de peixe e de penas apresentaram baixa solubilidade ruminal e alta digestibilidade intestinal, sendo a farinha de peixe levemente mais digerida no intestino do que a farinha de penas.

Palavras-chave: digestão, fermentação, rúmen, ruminantes

\section{Ruminal Degradability and Intestinal Digestibility of Feeds by Means of Associated Technical In Situ and Mobile Nylon Bag}

ABSTRACT - The objective of this work was to evaluate the ruminal degradation and intestinal and total dry matter (DM) and crude protein $(\mathrm{CP})$ digestibility of soybean meal, corn grain, dry molasses, fish meal, feather meal and alfalfa hay, by the in situ degradability technique associated to the mobile nylon bag technique. The samples of the feeds were milled and put in nylon bag of $10 \times 5 \mathrm{~cm}$ (48 micras) in the amounts of 15 and $5 \mathrm{mg}$ of DM/ $\mathrm{cm}^{2}$ for concentrate feeds and alfalfa hay, respectively. The nylon bags were incubated in the rumen of Holstein steers during $0 ; 2 ; 6 ; 8 ; 24$ and $48 \mathrm{~h}$; and $0 ; 8 ; 12 ; 24 ; 48 ; 72$ and 96 hours, respectively, and later were removed and inserted into the duodenum through a stem. The bags were collected with the feces. The values of effective degradability of CP for a rate of passage of 5\%/hour for the dry molasses, corn grain, soybean meal, fish meal, feather meal and alfalfa hay, were of 100.00, 62.50, 57.90, 39.30, 34.20 and $60.90 \%$, respectively; and intestinal digestibility of 100.00, 96.05, 99.79, 98.19, 96.07 and 94.64\%, respectively; and total digestibility of $100.00,97.86,99.87,98.88,97.35$ and $98.09 \%$, respectively. The proteins of the molasses were totally soluble at the rumen; and the corn, alfalfa hay and soybean meal were quite degraded, besides they have good total digestibility in the intestine. The proteins of the fish meal and feather meal have low ruminal degradability and high intestinal digestibility, and the fish meal is digested more slightly in the intestine than the feather meal.

Key Words: digestion, fermentation, rumen, ruminant

\section{Introdução}

As proteínas destacam-se, entre os outros nutrientes, pela amplitude de funções que desempenham no organismo animal. Portanto, é necessário conhecer a concentração protéica que os alimentos apresentam não só em quantidade, mas também em qualidade, para que dietas bem balanceadas com este nutriente possam promover o máximo desempenho dos animais (Ferreira, 1983).

Nos ruminantes os requerimentos protéicos devem ser supridos inicialmente pela digestão das pro-

\footnotetext{
1 Estudante de Doutorado - Departamento de Zootecnia/UFV. E.mail: marcusvm@alunos.ufv.br

2 Estudante de Doutorado em Zootecnia da Universidade Estadual Paulista (UNESP-Botucatu) - SP.

3 Professor Titular - Departamento de Zootecnia/ UFSM.

4 Mestre em Zootecnia.
} 
teínas microbianas que são sintetizadas no rúmen, seguidos pela digestão dos aminoácidos contidos nos alimentos que escapam da fermentação ruminal (Chalupa, 1980). No entanto, Orskov (1992) advertiu que a proporção de proteína dietética com baixa solubilidade ruminal deve ser aumentada simultaneamente com a exigência de produção do animal, já que as proteínas de origem microbiana fornecem uma quantidade de aminoácidos suficiente para suprir as exigências de manutenção e/ou proporcionar pequenos ganhos de peso.

Inicialmente, a avaliação da degradação dos alimentos, diretamente no rúmen de ovinos fistulados, utilizando sacos de material sintético, foi proposta por Quin et al. (1938). Posteriormente, inúmeros pesquisadores têm melhorado e adaptado esta técnica, tornando-a bastante utilizada, devido a sua rapidez, facilidade de execução, baixos custos e precisão. Atualmente, esta técnica também tem sido valorizada devido à tendência de se utilizarem nas formulações de rações os coeficientes "a"- fração solúvel do alimento degradada no tempo zero, "b"- fração insolúvel potencialmente degradável e "c"- taxa fracional de degradação da fração "b" por unidade de tempo (AFRC, 1993; NRC, 1996, 2001). Através destes coeficientes podem-se estimar os nutrientes necessários para o crescimento microbiano e aqueles requeridos pelo animal, maximizando assim a eficiência energética e protéica das rações (Andrade, 1994).

O AFRC (1992) sugeriu algumas regras para a execução da técnica in situ como um meio de padronização dos experimentos, sendo as principais relacionadas com a dieta do animal, preparação da amostra, quantidade de amostra, tamanho e porosidade do saco.

A determinação da digestibilidade intestinal da proteína na maioria dos sistemas é feita dividindo-se a proteína em duas partes, ou seja, aquela de origem microbiana (PM) e a de origem alimentar que não foi degradada no rúmen (PNDR).

Para se calcular a quantidade de PM que chega no intestino, é necessário saber qual será a síntese microbiana, sendo este cálculo variável com o sistema. De acordo com o NRC (1985), a produção bacteriana ocorre em função do NDT; com o AFRC (1993), ocorre em função da energia metabolizável fermentada no rúmen; e com o NRC (1996 e 2001), ocorre em função da quantidade de carboidratos totais degradados no rúmen. Todavia, a maioria dos sistemas adota digestibilidade intestinal microbiana média de 85,0\%. A digestibilidade da PNDR também é considerada constante, sendo que para o NRC (1985) e o AFRC (1993) é de 85,0 e 90,0\%, respectivamente. O NRC (1996) utiliza digestibilidades para proteína verdadeira de $100,0 \%$ para as frações $\mathrm{B}_{1}$ e $\mathrm{B}_{2} \mathrm{e}$ de $80,0 \%$ para a fração $\mathrm{B}_{3}$.

Este trabalho foi conduzido com o objetivo de avaliar a degradabilidade ruminal e a digestibilidade intestinal e total da matéria seca e da proteína bruta de alguns alimentos por intermédio das técnicas in situ e do saco de náilon móvel.

\section{Material e Métodos}

O trabalho foi conduzido no Setor de Nutrição Animal, pertencente ao Departamento de Zootecnia da Universidade Federal de Santa Maria (UFSM), no Rio Grande do Sul. O estudo do desaparecimento ruminal, intestinal e total foi feito por intermédio da técnica de degradabilidade in situ associada à técnica do saco de náilon móvel, seguindo-se os procedimentos descritos por Hernandez (1995). O ensaio teve duração de 21 dias, sendo 10 dias para a adaptação dos animais e 11 dias para coleta dos dados.

Foram usados dois bois holandeses, com peso vivo médio de $450 \mathrm{~kg}$, providos de cânulas ruminal e duodenal (cânula do tipo " T " feita de PVC e inserida logo após o abomaso). A dieta dos animais seguiu as normas do AFRC (1992) e manteve uma relação de $60 \%$ de feno de alfafa de alta qualidade e $40 \%$ de concentrado, constituído de grão de milho, farelo de soja, farinha de peixe, farinha de penas e minerais (Tabela 1). No início do ensaio, o consumo foi à vontade, sendo, posteriormente, reduzido ao nível de manutenção. A dieta foi fornecida parcelada em intervalos de 4 horas. Os animais permaneceram em baias individualizadas providas de cocho e bebedouro automático, dentro de um galpão de alvenaria.

Avaliaram-se cinco alimentos concentrados, sendo três de origem vegetal (farelo de soja, grão de milho e melaço em pó) e dois de origem animal (farinhas de peixe e de penas) e um volumoso (feno de alfafa). As amostras dos alimentos foram moídas em peneira com perfurações de 1 e $4 \mathrm{~mm}$ e colocadas em sacos de náilon de $10 \times 5 \mathrm{~cm}$, com porosidade de 48 micras, nas quantidades de 15 e $5 \mathrm{mg}$ de $\mathrm{MS} / \mathrm{cm}^{2}$, para os alimentos concentrados e para o volumoso, respectivamente. Os sacos foram identificados com tinta insolúvel e, posteriormente, fechados a quente com uma seladora automática. Existiam dois sacos para cada alimento por tempo de incubação por animal. 
Tabela 1 - Composição percentual, na matéria seca, da dieta oferecida aos animais

Table 1 - Percentage composition, in dry matter, of the diet offered to the animals

\begin{tabular}{lc}
\hline $\begin{array}{l}\text { Ingredientes } \\
\text { Ingredients }^{*}\end{array}$ & $\begin{array}{c}\text { Dieta } \\
\text { Diet }\end{array}$ \\
\hline $\begin{array}{l}\text { Feno de alfafa } \\
\text { Alfalfa hay }\end{array}$ & 60,0 \\
Grão de milho & \\
$\begin{array}{l}\text { Corn grain } \\
\text { Melaço em pó } \\
\text { Dry molasses }\end{array}$ & 20,0 \\
$\begin{array}{l}\text { Farelo de soja } \\
\text { Soybean meal }\end{array}$ & 1,0 \\
$\begin{array}{l}\text { Farinha de peixe } \\
\text { Fish meal }\end{array}$ & \\
$\begin{array}{l}\text { Farinha de penas } \\
\text { Feather meal } \\
\text { Mistura mineral }\end{array}$ & 8,0 \\
Mineral mixture \\
Total
\end{tabular}

* Teores de proteína bruta, na matéria seca, do feno de alfafa, grão de milho, melaço em pó, farelo de soja, farinha de peixe e farinha de penas: 22,$79 ; 8,07 ; 2,87 ; 43,77 ; 62,33$ e $70,89 \%$, respectivamente.

${ }^{*}$ Contents of crude protein, in the dry matter, of the alfalfa hay, corn grain, dry molasses, soybean meal, fish meal and feathers meal: 22.79, 8.07, $2.87,43.77,62.33$ and $70.89 \%$, respectively

Os procedimentos de incubação seguiram as recomendações do AFRC (1992), sendo que o método adotado foi o de incubação seqüencial, ou seja, com colocação inicial dos sacos que mais permaneceram no rúmen, retirando-se todos no mesmo momento, ou seja, no tempo zero. Os sacos com o mesmo tempo de incubação foram colocados dentro de um saco de poliamida $(12,5 \times 21 \mathrm{~cm})$, com malha de $1 \mathrm{~mm}$, sendo este fixado a uma âncora, com um peso total de $250 \mathrm{~g}$. Esta foi presa a um fio de náilon com cerca de $50 \mathrm{~cm}$ de comprimento, de modo que garantisse imediata imersão e movimentação do saco no conteúdo ruminal, sendo a ponta do fio de náilon mantida presa pelo lado de fora da cânula. Os tempos de incubação dos alimentos concentrados foram de $0 ; 2 ; 6 ; 8 ; 24$ e 48 horas e do feno alfafa, de $0 ; 8 ; 12 ; 24 ; 48 ; 72$ e 96 horas.

Ao final do ensaio de degradabilidade in situ, todos os sacos foram retirados do rúmen e, juntamente com os sacos do tempo zero, lavados por turbilhonamento até que a água ficasse completamente limpa. Como havia dois sacos para cada alimento por tempo por animal, um foi colocado em estufa regulada a $60^{\circ} \mathrm{C}$ por 24 horas, e o outro foi congelado para posterior determinação da digestibilidade intestinal.

O descongelamento dos sacos foi feito em tem- peratura ambiente, sendo inseridos seis sacos a cada 8 horas, com intervalos de 5 minutos entre cada introdução, conforme descrito por Hernandez (1995). À medida que os sacos eram recuperados nas fezes, eram imediatamente lavados por turbilhonamento e secos em estufa regulada a $60^{\circ} \mathrm{C}$, por 24 horas.

Em todos os sacos incubados no rúmen e naqueles recuperados nas fezes, foram feitas análises para determinação dos teores de matéria seca (MS) e de proteína bruta (PB). Os sacos que apresentaram quantidade de resíduo de, aproximadamente, 1,0 g (normalmente nos de incubação ruminal) foram cortados e o teor protéico do resíduo, analisado pelo procedimento do micro Kjeldahl. Naqueles sacos onde a quantidade residual foi menor que $1,0 \mathrm{~g}$ (normalmente nos de incubação intestinal), o teor protéico no resíduo foi analisado, digerindo-se todo o saco, por intermédio da técnica do macro Kjeldahl, adaptada dos procedimentos descritos por Silva (1990).

A determinação da percentagem de MS e PB que desapareceu ruminalmente, em cada tempo, foi feita da seguinte forma: Desaparecimento ruminal da MS ou da PB $=[(\mathrm{g}$ de MS ou de PB incubada - $\mathrm{g}$ de MS ou de PB residual, após a incubação ruminal) / g de MS ou de PB incubada] x 100. Posteriormente, para estimativa dos parâmetros de degradação ruminal da MS e da PB, utilizaram-se os dados de desaparecimento obtidos após incubação nos diferentes tempos. Os dados das degradações parciais foram ajustados ao modelo descrito por Orskov \& McDonald (1979), qual seja: $\mathrm{Dg}=\mathrm{a}+\mathrm{b}$ (1-exp-ct), em que "a" é a fração solúvel degradada no tempo zero; "b", a fração insolúvel potencialmente degradável; "c", a taxa fracional de degradação da fração " $b$ " por unidade de tempo; e "t", o tempo de incubação. A degradabilidade efetiva (Dge) de cada alimento foi calculada pela fórmula: Dge $=a+[(b * c) /(c+k)]$, em que "k" é a taxa de passagem, conforme descrito por Orskov \& McDonald (1979).

Os dados de desaparecimento total da MS e da PB foram assim determinados: Desaparecimento total da MS ou da PB $=\{[$ (g de MS ou de PB incubada - $\mathrm{g}$ de MS ou de PB residual após passagem pelo trato gastrintestinal) / g de MS ou de PB incubada] x 100\}. O desaparecimento intestinal foi calculado pela diferença entre os valores de desaparecimento total e o ruminal. A digestibilidade intestinal foi calculada da seguinte forma: Digestibilidade Intestinal $=[(\mathrm{g}$ de MS ou de PB absorvida no intestino / g de MS ou de PB que chegou ao intestino) $x$ 100]. 


\section{Resultados e Discussão}

O desaparecimento ruminal da MS e da $\mathrm{PB}$ dos alimentos analisados aumentou em função do tempo de incubação, ocorrendo o inverso com o desaparecimento intestinal. Assim, a quantidade de MS e de PB que chegou ao intestino foi dependente da quantidade de resíduo após a degradação ruminal, sendo esta, variável de acordo com o tempo de incubação. Na Tabela 2, são apresentados os coeficientes "a", "b" e "c" (Orskov \& McDonald, 1979); as degradabilidades efetivas para as taxas de passagem de 2; 5 e 8\%/hora; e os valores médios percentuais da digestibilidade intestinal e total da MS e da PB de cada alimento. Nas Figuras 1 e 2, são evidenciados os valores percentuais da degradabilidade potencial da MS e PB, respectivamente, em função dos tempos de incubação ruminal.

Os dados de degradabilidade efetiva da MS, considerando taxa de passagem de $5 \% / \mathrm{h}$, mostraram que o melaço foi totalmente degradado no rúmen ( $100,0 \%$ de solubilidade), sendo este dado enfatizado pelo coeficiente "a" de 100,0\%. Após o melaço, o farelo de soja, o grão de milho e o feno de alfafa foram os alimentos mais degradados com 69,2;66,9 e $64,0 \%$, respectivamente. As farinhas de peixe e de penas apresentaram as menores degradabilidades, com 35,0 e $32,9 \%$, respectivamente. As diferentes tendências de degradabilidade potencial da MS, em função do tempo, desses alimentos, podem ser melhor observadas na Figura 1.

Os valores dos coeficientes "a", "b" e "c" do grão de milho e do farelo de soja foram semelhantes, indicando que ambos tiveram elevada degradação da MS em nível de rúmen. Rossi Jr. et al. (1997), Martins et al. (1998) e Valadares Filho (1994) também encontraram valores semelhantes de degradabilidade da MS para o farelo de soja. No

Tabela 2 - Valores de "a", "b", "c"; degradabilidades efetivas para taxas de passagem de 2; 5 e $8 \% / h$; e valores médios percentuais de digestibilidade intestinal (DI) e total (DT) da matéria seca (MS) e proteína bruta (PB)

Table 2 - Values of "a", " $b$ ", "c"; effective degradability for rate of passage of 2, 5 and $8 \% / h$; and percent mean values of intestinal (ID) and total (TD) digestibility of the dry matter (DM) and crude protein (CP)

\begin{tabular}{|c|c|c|c|c|c|c|c|c|}
\hline $\begin{array}{l}\text { Alimentos } \\
\text { Feeds }\end{array}$ & $\begin{array}{l}\text { 'a'" } \\
(\%)\end{array}$ & $\begin{array}{l}\text { 'b" } \\
(\%)\end{array}$ & $\begin{array}{l}\text { 'c'" } \\
(/ \mathrm{h})\end{array}$ & $2 \% / \mathrm{h}$ & $5 \% / \mathrm{h}$ & $8 \% / h$ & $\begin{array}{l}\mathrm{DI} \\
I D\end{array}$ & $\begin{array}{l}\text { DT } \\
T D\end{array}$ \\
\hline \multicolumn{9}{|l|}{$\begin{array}{l}\text { Matéria seca } \\
\text { Dry matter }\end{array}$} \\
\hline $\begin{array}{l}\text { Grão de milho } \\
\text { Grain corn }\end{array}$ & 32,09 & 67,91 & 0,0525 & 81,30 & 66,90 & 59,00 & 73,82 & 90,41 \\
\hline $\begin{array}{l}\text { Melaço em pó } \\
\text { Dry molasses }\end{array}$ & 100,0 & - & - & 100,00 & 100,00 & 100,00 & 100,00 & 100,00 \\
\hline $\begin{array}{l}\text { Farelo de soja } \\
\text { Soybean meal }\end{array}$ & 36,07 & 63,93 & 0,0538 & 82,70 & 69,20 & 61,80 & 88,56 & 95,79 \\
\hline $\begin{array}{l}\text { Farinha de peixe } \\
\text { Fish meal }\end{array}$ & 26,51 & 73,49 & 0,0065 & 44,60 & 35,00 & 32,10 & 80,50 & 87,12 \\
\hline $\begin{array}{l}\text { Farinha de penas } \\
\text { Feather meal }\end{array}$ & 22,44 & 15,79 & 0,0982 & 35,60 & 32,90 & 31,10 & 79,67 & 86,01 \\
\hline $\begin{array}{l}\text { Feno de alfafa } \\
\text { Alfalfa hay }\end{array}$ & 35,61 & 40,45 & 0,1171 & 70,20 & 64,00 & 59,60 & 18,64 & 73,96 \\
\hline \multicolumn{9}{|l|}{$\begin{array}{l}\text { Proteína bruta } \\
\text { Crude protein }\end{array}$} \\
\hline $\begin{array}{l}\text { Grão de milho } \\
\text { Grain corn }\end{array}$ & 18,46 & 81,54 & 0,0588 & 79,30 & 62,50 & 53,00 & 96,05 & 97,86 \\
\hline $\begin{array}{l}\text { Melaço em pó } \\
\text { Dry molasses }\end{array}$ & 100,0 & - & - & 100,00 & 100,00 & 100,00 & 100,00 & 100,00 \\
\hline $\begin{array}{l}\text { Farelo de soja } \\
\text { Soybean meal }\end{array}$ & 16,45 & 83,55 & 0,0493 & 75,90 & 57,90 & 48,30 & 99,79 & 99,87 \\
\hline $\begin{array}{l}\text { Farinha de peixe } \\
\text { Fish meal }\end{array}$ & 30,00 & 35,30 & 0,0180 & 46,70 & 39,30 & 36,50 & 98,19 & 98,88 \\
\hline $\begin{array}{l}\text { Farinha de penas } \\
\text { Feather meal }\end{array}$ & 23,30 & 15,71 & 0,1169 & 36,60 & 34,20 & 32,50 & 96,07 & 97,35 \\
\hline $\begin{array}{l}\text { Feno de alfafa } \\
\text { Alfalfa hay }\end{array}$ & 25,75 & 49,82 & 0,1197 & 68,40 & 60,90 & 55,60 & 94,64 & 98,09 \\
\hline
\end{tabular}

R. Bras. Zootec., v.32, n.6, p.2023-2031, 2003 (Supl. 2) 
entanto, os valores de degradabilidade efetiva do farelo de soja e do grão de milho, neste trabalho, foram inferiores aos descritos pelo NRC (1985), por Castillo (1992) e Almeida et al. (1993). As duas fontes de origem animal apresentaram baixa degradabilidade ruminal (Figura 1). Contudo, a farinha de peixe apresentou a maior fração " $b$ " e a menor taxa "c", indicando ser uma fonte potencialmente degradável no rúmen, mas sob lenta taxa de degradação. Estes resultados são coerentes com os descritos

Tempo de incubação ruminal (horas) Time of incubation (hours)

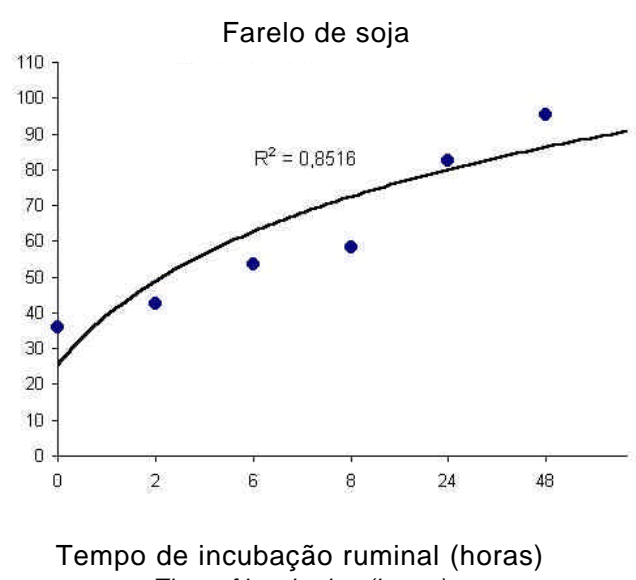
Time of incubation (hours)
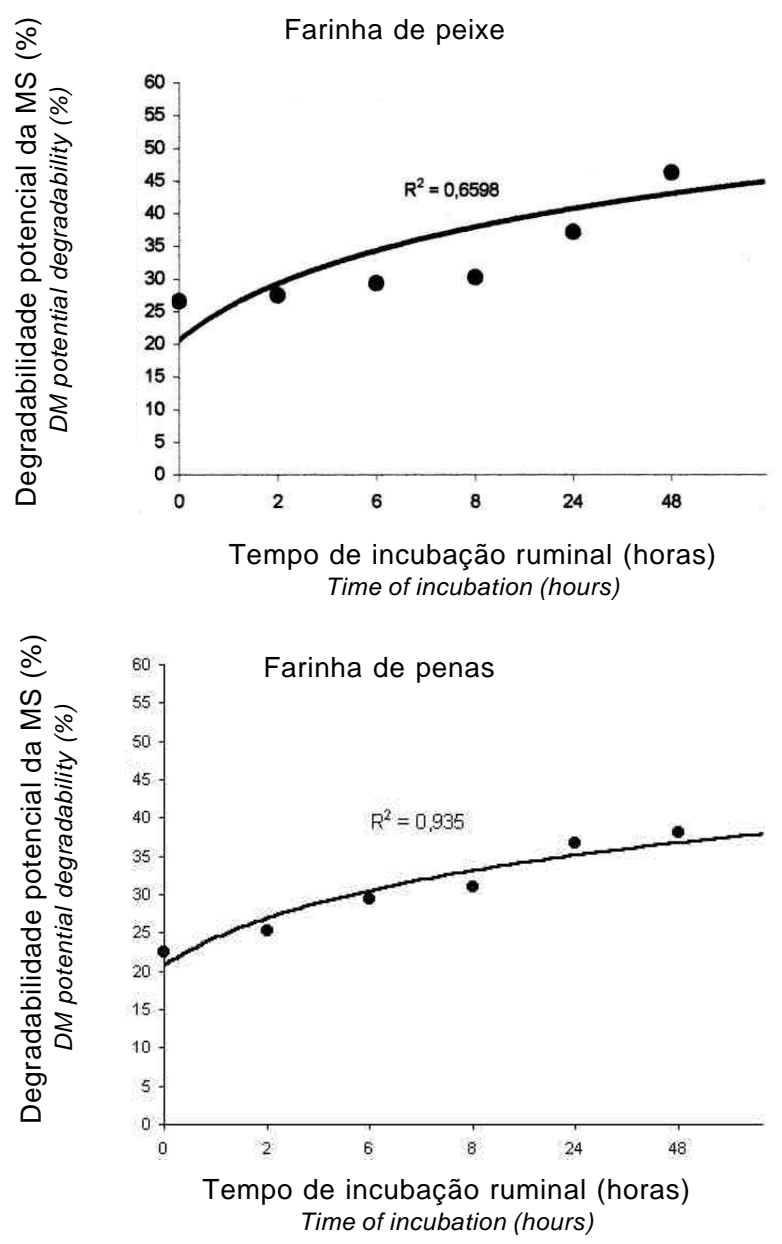

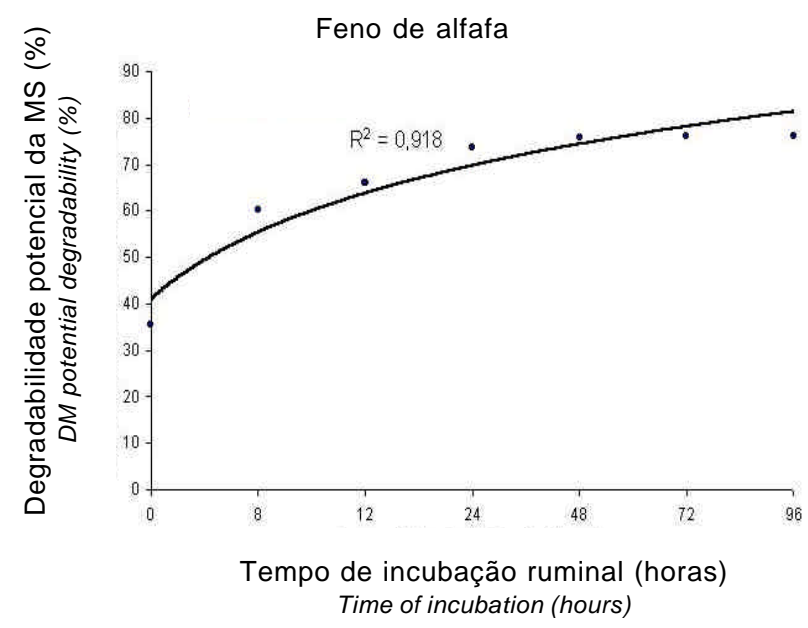

Figura 1 - Degradabilidade potencial da matéria seca (MS) dos alimentos, em função do tempo de incubação. Figure 1 - Potential degradability of the dry matter (DM) of the feeds, in function of the time of incubation.

R. Bras. Zootec., v.32, n.6, p.2023-2031, 2003 (Supl. 2) 
por Valadares Filho (1994). Contudo, os valores médios de degradabilidade efetiva para uma taxa de passagem ruminal de $5 \% / \mathrm{h}$ descritos por este autor foram de 20,5 e $21,1 \%$ para as farinhas de peixe e a de penas mais sangue, respectivamente, sendo, portanto inferiores aos obtidos neste experimento. $\mathrm{O}$ feno de alfafa apresentou uma fração "b" superior à "a", o que lhe confere boa degradabilidade da MS. No entanto, esta degradação ocorreu rapidamente, como pode ser observado pelo elevado valor da taxa "c" $(0,1171 / \mathrm{h})$.

O desaparecimento médio da MS em nível intestinal indicou que o melaço foi o alimento mais aproveitável no intestino, sendo seguido pelo farelo de soja, pelas farinhas de peixe e de penas, pelo grão de milho e pelo feno de alfafa, com uma digestibilidade de 100,$0 ; 88,56 ; 80,50 ; 79,67 ; 73,82$ e $18,64 \%$, respectivamente. Este aproveitamento foi influenciado pela degradabilidade ruminal e, conseqüentemente, pela quantidade de alimento que chegou ilesa ao intestino. Tanto a farinha de peixe como a farinha de penas, apresentaram aproveitamento semelhante em nível intestinal e total, com cerca de 80,0 e $86,0 \%$, respectivamente, indicando que estas fontes são aproveitadas de modo similar no trato gastrintestinal dos ruminantes. A digestibilidade total da MS do melaço, farelo de soja e grão de milho indicaram que estes alimentos foram altamente aproveitados (média de $95,4 \%$ de digestibilidade). A menor digestão total foi verificada com o feno de alfafa com $73,96 \%$, sendo este valor um reflexo da percentagem de material indigerível, tanto em nível de rúmen como de intestino.

Em relação aos dados de degradabilidade efetiva da PB para uma taxa de passagem ruminal de $5 \% / \mathrm{h}$, verificou-se que as proteínas do melaço foram totalmente solúveis no rúmen, com 100,0\% de degradabilidade, seguidas pelas do grão de milho, do farelo de soja e do feno de alfafa, este último com cerca de $60,0 \%$. As fontes protéicas de origem animal apresentaram as menores degradabilidades efetivas, de 39,3 e 34,2\%, para as farinhas de peixe e de penas, respectivamente. As diferentes tendências de degradabilidade potencial da PB em função do tempo, desses alimentos podem melhor visualizadas na Figura 2.

De acordo com o AFRC (1993), a degradabilidade efetiva da PB do farelo de soja para uma taxa de passagem ruminal de $6 \% /$ h deve ser de $60,0 \%$. Já Martins et al. (1998) encontrou, para taxa de passagem no rúmen de $5 \% / \mathrm{h}$, degradabilidade de $57,3 \%$. Os valores obtidos neste experimento corroboram os desses autores. No entanto, Valadares Filho (1994) e Hernandez et al. (1998) encontraram degradabilidades superiores para o farelo de soja de 65,50 $(61,50$ a 70,70$)$ e $72,36 \%$, respectivamente. Degradabilidades efetivas inferiores para o grão de milho e para a farinha de peixe, de $42,80(36,60$ a 49,90) e $23,50 \%(22,20$ a $24,80 \%$ ), respectivamente, e levemente superior $(35,9 \%)$ para a farinha de penas mais sangue foram verificados por Valadares Filho (1994). Hernandez et al. (1998) também verificaram degradabilidade superior $(54,6 \%)$ para a farinha de penas.

O melaço em pó demonstrou ser um alimento cuja PB é totalmente solúvel no rúmen, sendo este valor igual ao descrito no AFRC (1993). A PB do farelo de soja e do grão de milho demonstraram ter características de degradação semelhantes (Figura 2), apresentando as menores frações "a" e as mais altas frações "b", indicando serem altamente degradáveis no rúmen. Resultados semelhantes também foram descritos por Valadares Filho (1995) para a PB do farelo de soja e a do milho na forma de fubá. A farinha de penas foi a que apresentou a maior fração "c", com $0,1169 /$ h e baixos valores das frações "a" e "b", indicando ser sua $\mathrm{PB}$ pouco degradável no rúmen, mas com rápida solubilização. A PB da farinha de peixe também demonstrou ser pouco degradada, contudo apresentou taxa de degradação superior à da farinha de penas (Figura 2). Menores valores dos coeficientes "a", "b" e "c" para a PB da farinha de peixe foram descritos por Valadares Filho et al. (1991) e por Castillo (1992). No entanto, valores superiores para os coeficientes "b" e "c" da PB da farinha de peixe foram descritos no AFRC (1993). Vilela (1994) também encontrou valor superior para a fração "b" da PB da farinha de penas, sendo este resultado também coerente com o descrito no AFRC (1993).

A PB do farelo de soja e do grão de milho apresentaram elevado aproveitamento no intestino, em média com $98,0 \%$ de digestibilidade, possivelmente devido à alta degradabilidade ruminal, associada à pequena quantidade de alimento que chegou e foi digerida no intestino. Estes alimentos também apresentaram alta digestibilidade total da PB $(99,0 \%$, em média). Do eventual aporte ao intestino de elevadas quantidades destes alimentos, possivelmente estes poderiam ter sua PB totalmente digeridas e absorvidas. Este tipo de situação poderá ocorrer quando houver alto consumo associado à elevada taxa de passagem, quando estes alimentos permanecendo menos tempo no rúmen, serão pouco degradados. 

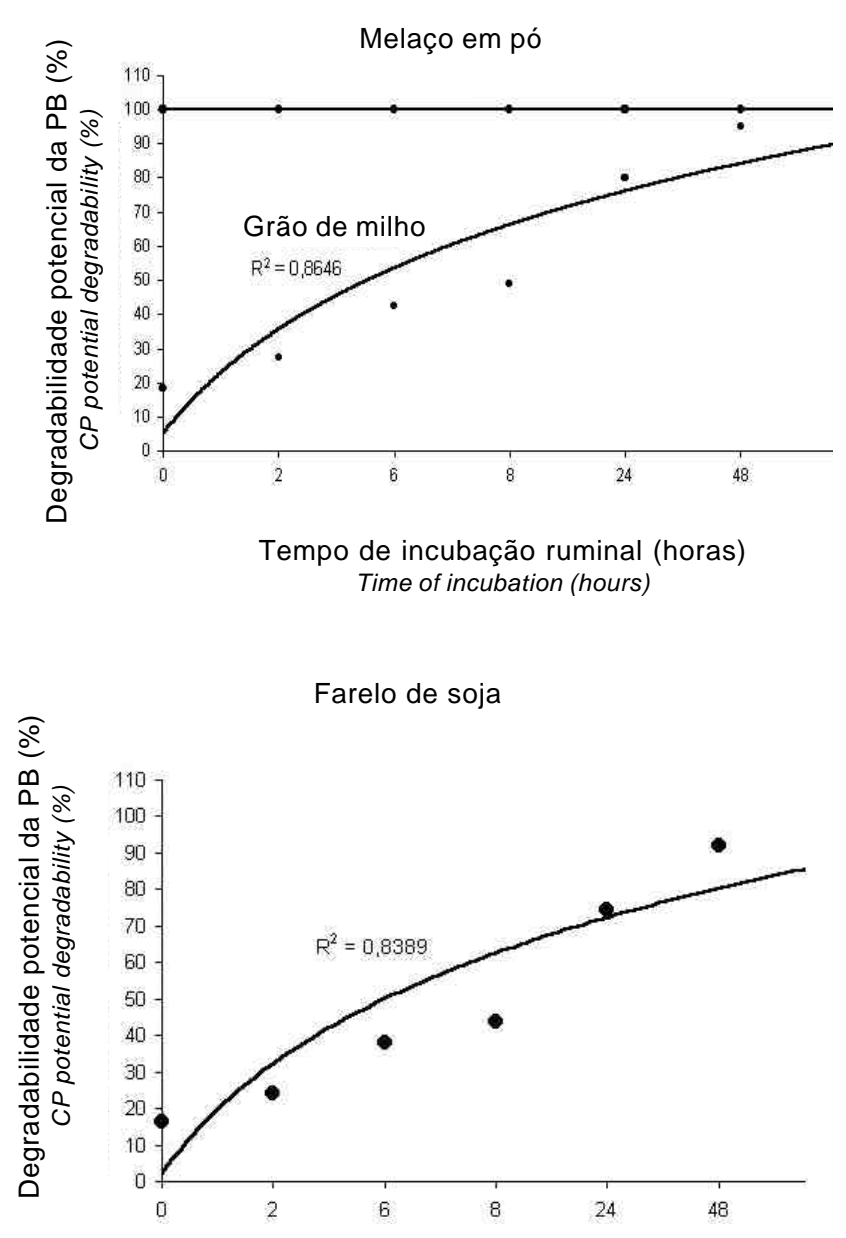

Tempo de incubação ruminal (horas) Time of incubation (hours)
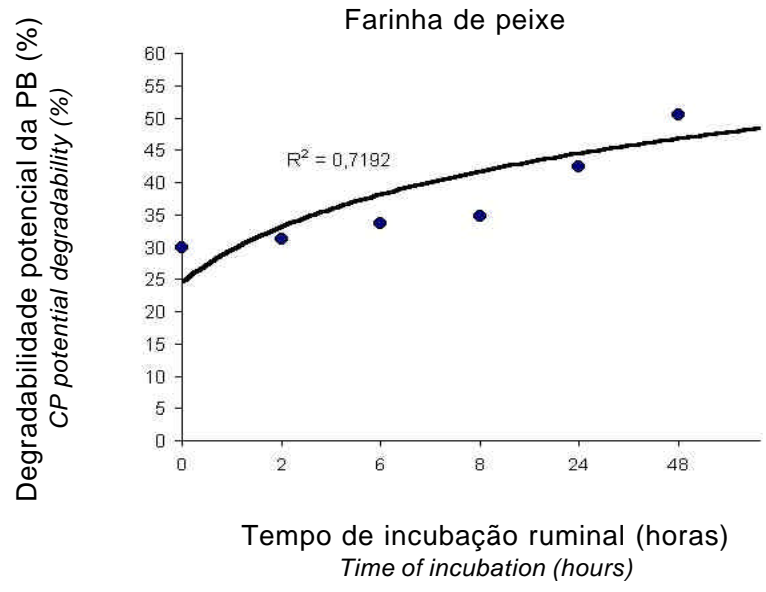

Farinha de penas
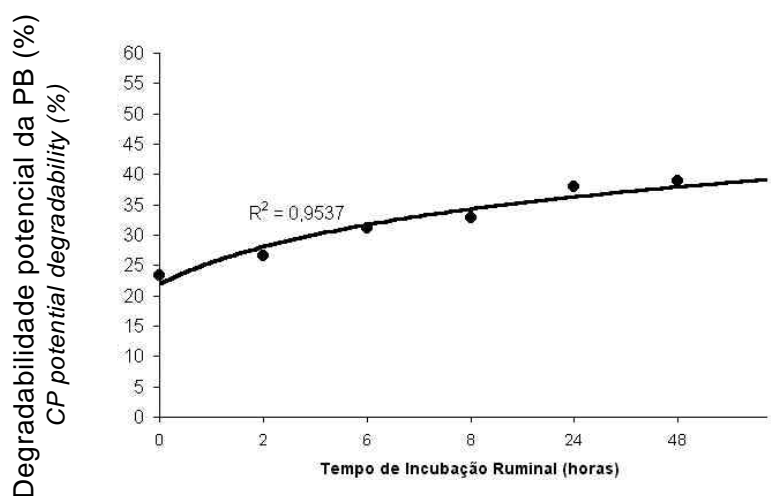

Tempo de incubação ruminal (horas) Time of incubation (hours)

Feno de alfafa
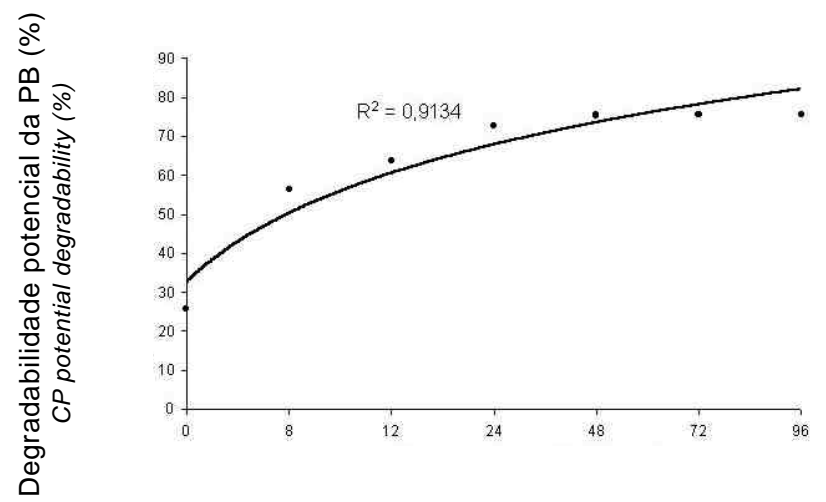

Tempo de incubação ruminal (horas) Time of incubation (hours)

Figura 2 - Degradabilidade potencial da proteína bruta (PB) dos alimentos, em função do tempo de incubação. Figure 2 - Potential degradability of the crude protein $(C P)$ of the feeds, in function of the time of incubation.

Desse modo, estes alimentos assemelham-se às fontes com baixa degradabilidade ruminal, como as farinhas de peixe e de penas. Castillo (1992) e Ramos et al. (1995) também encontraram valores de desapa- recimento ruminal semelhantes para o milho na forma de fubá e para o farelo de soja. No entanto, os coeficientes de digestibilidade obtidos por estes autores foram inferiores aos descritos neste trabalho.

\section{R. Bras. Zootec., v.32, n.6, p.2023-2031, 2003 (Supl. 2)}


A PB da farinha de peixe apresentou, em média, desaparecimento intestinal inferior à da farinha de penas $(61,49$ e $65,56 \%$, respectivamente). Contudo, isto se inverteu para os dados de digestibilidade, com 98,19 e $96,07 \%$, respectivamente. A farinha de peixe apresentou ainda, em média, maior desaparecimento ruminal da $\mathrm{PB}$ em relação ao da farinha de penas (37,39 e $31,78 \%$, respectivamente). No entanto, ambas apresentaram, em média, aproveitamento total da PB de $98,11 \%$, diferenciando-as, portanto, no perfil de seus aminoácidos. Nesta pesquisa, foram obtidos resultados semelhantes aos de Keery et al. (1993), em relação ao farelo de soja e à farinha de peixe, sendo que a digestão da MS no rúmen foi maior para os novilhos alimentados com farelo de soja, mas a digestibilidade total não foi afetada pela fonte protéica. Howie et al. (1996) estudaram a digestão da PB em nível intestinal de sete farinhas de penas, obtendo digestibilidade média de $65,30 \%$ (59,0 a $75,20 \%)$, valores inferiores aos deste trabalho. Hernandez et al. (1998) também encontraram valores de desaparecimento intestinal inferiores para a farinha de penas; todavia, os valores de desaparecimento do farelo de soja foram semelhantes.

\section{Conclusões}

O melaço em pó é um alimento totalmente solúvel no rúmen. Fontes protéicas de origem animal como as farinhas de peixe e de penas apresentam baix degradabilidade ruminal. $O$ feno de alfafa de alta qualidade nutritiva apresentou, de modo similar ao grão de milho e ao farelo de soja elevada degradabilidade.

O desaparecimento intestinal é variável com o tempo de incubação ruminal, com a quantidade de alimento que chega ao intestino e com o tipo de alimento utilizado.

Como se verificou grande heterogeneidade entre os alimentos em relação à forma de aproveitamento no trato gastrintestinal, alimentos como o grão de milho, farelo de soja e as farinhas de peixe e pena, que possuem alta e baixa degradabilidade ruminal, respectivamente, tornam-se essenciais principalmente nos sistemas de cálculo de rações que se baseiam na proteína metabolizável. Os alimentos mais degradáveis ruminalmente podem ser utilizados para maximizar o desenvolvimento microbiano, e os menos degradáveis, mas digeríveis em nível intestinal, para fornecer aminoácidos diretamente no intestino delgado.

\section{Literatura Citada}

AGRICULTURAL AND FOOD RESEARCH COUNCIL AFRC. Energy and protein requirements of ruminants. An advisory manual prepared by the AFRC Technical Committee on Responses to Nutrients. Wallingford, UK: CAB International, 1993. 159p.

AGRICULTURAL AND FOOD RESEARCH COUNCILAFRC. Nutritive requirements of ruminants animals protein. Nutrition Abstracts and Reviews (Series B), v.62, n.12, p.787-835, 1992.

ALMEIDA, G.A.P.; VALADARES FILHO, S.C.; COELHO DA SILVA, J.F. et al. Degradabilidade in situ da matéria seca e proteína bruta dos ingredientes de cinco rações concentradas, contendo diferentes níveis de degradabilidade de proteína bruta no rúmen, fornecidas para vacas em lactação. In: REUNIÃO ANUAL DA SOCIEDADE BRASILEIRA DE ZOOTECNIA, 30., 1993, Rio de Janeiro. Anais... Rio de Janeiro: Sociedade Brasileira de Zootecnia, 1993. p.417.

ANDRADE, P. Técnica "in situ" (saco de náilon) na avaliação de alimentos para ruminantes. Simpósio Internacional de Produção de Ruminantes. In: REUNIÃO ANUAL DA SOCIEDADE BRASILEIRA DE ZOOTECNIA, 31, 1994, Maringá. Anais... Maringá: Sociedade Brasileira de Zootecnia, 1994. p.141-147.

CASTILLO, A.M.A. Avaliação da degradabilidade ruminal e da digestibilidade intestinal de vários alimentos, utilizando-se a técnica do saco de náilon móvel. Viçosa, MG: Universidade Federal de Viçosa, 1992. 108p. Dissertação (Mestrado em Zootecnia) - Universidade Federal de Viçosa, 1992.

CHALUPA, W. Methods for estimating protein requirements and feed protein values for ruminants. Feedstuffs, p.18-20, 1980.

FERREIRA, J.J. Proteína e concentrados protéicos na alimentação de ruminantes. Informe Agropecuário, v.9, n.108, p.43-48, 1983.

HERNANDEZ, F.I.L. Avaliação da técnica do saco de náilon móvel para determinação do desaparecimento ruminal e intestinal da matéria seca e proteína bruta. Santa Maria: Universidade Federal de Santa Maria, 1995. 127p. Dissertação (Mestrado em Zootecnia) - Universidade Federal de Santa Maria, 1995.

HERNANDEZ, F.I.L.; SANCHEZ, L.M.B.; VIEIRA, R.A.M. et al. Desaparecimento ruminal e digestibilidade intestinal e total da matéria seca e proteína bruta de alguns suplementos concentrados. Revista Brasileira de Zootecnia, v.27, n.4, p.777-782, 1998.

HOWIE, S.A.; CALSAMIGLIA, S.; STERN, M.D. Variation in ruminal degradation and intestinal digestion of animal by product proteins. Animal Feed Science and Technology, v.73, p.1-7, 1996.

KEERY, C.M.; AMOS, H.E.; FROETSCHEL, M.A. Effects of supplemental protein source of intraruminal fermentation, protein degradation, and amino acid absorption. Journal of Dairy Science, v.76, p.514-524, 1993.

MARTINS, A.S.; ZEOULA, L.M.; PRADO, I.N. et al. Degradação ruminal da matéria seca e proteína bruta de alguns alimentos. In: REUNIÃO ANUAL DA SOCIEDADE BRASILEIRA DE ZOOTECNIA, 35, 1998, Botucatu. Anais... Botucatu: Sociedade Brasileira de Zootecnia, 1998. CDROM. Nutrição de Ruminantes. RUM 063.

NATIONAL RESEARCH COUNCIL - NRC. Nutrient

R. Bras. Zootec., v.32, n.6, p.2023-2031, 2003 (Supl. 2) 
requirements of beef cattle. 7.rev.ed. Washington, D.C.: National Academy of Sciences, 1996. 233p.

NATIONAL RESEARCH COUNCIL - NRC. Ruminant nitrogen usage. Washington, D.C.: National Academy of Sciences, 1985. 158p.

NATIONAL RESEARCH COUNCIL - NRC. Ruminant requirements of dairy cattle. Washington, D.C.: National Academy of Sciences. 7.rev.ed. 2001. 381p.

ORSKOV, E.R. Protein nutrition in ruminants. 2.ed. International Feed Resources Unit. The Rowett Research Institute. Aberdeen Academic Press, 1992. 175p.

ORSKOV, E.R.; Mc DONALD, I. The estimation of protein degradability in the rumen from incubation measurements weighted according to rate of passage. Journal of Agricultural Science, v.92, p.499-503, 1979.

QUIN, J.L.; Van der WATH, J.G.; MYBURGIN, S. Studies on the alimentary tract of merino sheep in South Africa. 4Description of experimental technique. Onderstepoort, Journal of Veterinary Science and Animal Industry, v.11, p.341-360, 1938

RAMOS, S.M.; VALADARES FILHO, S.C.; COELHO DA SILVA, J.F. et al. Digestibilidade intestinal dos alimentos com a técnica do saco de náilon móvel em novilhos cecocolectomizados. In: REUNIÃO ANUAL DA SOCIEDADE BRASILEIRA DE ZOOTECNIA, 32., 1995, Brasília. Anais... Brasília: Sociedade Brasileira de Zootecnia, 1995. p. 247-249.

ROSSI JUNIOR, P.; SILVA, A.G.; WANDERLEY, R.C. et al. Degradabilidade ruminal da matéria seca e da fração protéica da silagem de milho, do farelo de soja e do sorgo em grão, em bovinos da raça nelore. Comparação com os dados obtidos pelo CNCPS. Revista Brasileira de Zootecnia, v.26, n.3, p.599-607, 1997.
SILVA, D.J. Análise de alimentos (Métodos químicos e biológicos). Viçosa, MG: Universidade Federal de Viçosa, 1990. 160p.

VALADARES FILHO, S.C. Eficiência de síntese de proteína microbiana, degradação ruminal e digestibilidade intestinal da proteína bruta, em bovinos. In: SIMPÓSIO INTERNACIONAL SOBRE EXIGÊNCIAS NUTRICIONAIS DE RUMINANTES, 1995, Viçosa, MG. Anais... Viçosa: Universidade Federal de Viçosa, 1995. p.355-388.

VALADARES FILHO, S.C. Utilização da técnica "in situ" para a avaliação dos alimentos. Simpósio Internacional de Produção de Ruminantes. In: REUNIÃO ANUAL DA SOCIEDADE BRASILEIRA DE ZOOTECNIA, 31., 1994, Paraná. Anais... Maringá: Sociedade Brasileira de Zootecnia, 1994. p.95-118.

VALADARES FILHO, S.C.; COELHO da SILVA, J.F.; LEÃO, M.I. Degradabilidade ' 'in situ' da proteína bruta e da matéria seca de alguns alimentos em vacas gestantes e lactantes. Revista da Sociedade Brasileira de Zootecnia, v.20, n.1, p.111-122, 1991.

VILELA, G.L. Degradabilidade "'in situ" da matéria seca e proteína bruta de vários alimentos em vacas alimentadas com diferentes rações. Viçosa, MG: Universidade Federal de Viçosa, 1994. 68p. Dissertação (Mestrado em Zootecnia) - Universidade Federal de Viçosa, 1994.

Recebido em: 19/02/02 Aceito em: 30/04/03 